Cahiers du MONDE RUSSE

\section{Cahiers du monde russe}

Russie - Empire russe - Union soviétique et États indépendants

40/1-2 | 1999

Archives et nouvelles sources de l'histoire soviétique, une réévaluation

\title{
Researching Stalin's nationality policy in the archives
}

Peter A. Blitstein

\section{(2) OpenEdition \\ 1 Journals}

Electronic version

URL: http://journals.openedition.org/monderusse/7

DOI: $10.4000 /$ monderusse.7

ISSN: $1777-5388$

Publisher

Éditions de l'EHESS

\section{Printed version}

Date of publication: 1 January 1999

Number of pages: 125-138

ISBN: 2-7132-1314-2

ISSN: $1252-6576$

Electronic reference

Peter A. Blitstein, "Researching Stalin's nationality policy in the archives », Cahiers du monde russe

[Online], 40/1-2 | 1999, Online since 15 January 2007, Connection on 02 May 2019. URL : http://

journals.openedition.org/monderusse/7 ; DOI : 10.4000/monderusse.7 


\section{RESEARCHING NATIONALITY POLICY IN THE ARCHIVES*}

IT IS TOO SOON TO DETERMINE whether increased access to archival sources will lead to significant advances in historical understanding of the Soviet experience. Problems of unequal and uneven access to collections, financial difficulties afflicting the archives themselves, and the lack of a tradition of source criticism among, especially, Western specialists are serious obstacles to such an improvement. If all this is true for future work on Soviet history in general, it is especially true for nationality policy, which is perhaps the most under-researched and poorly understood aspect of Soviet history. ${ }^{1}$ The historiography of Soviet nationality policy, based on scanty, mainly published, sources, was caught too often between official Soviet apologetics and anti-Soviet prosecutorial nationalism. Good research on nationality policy not only requires the overcoming of the ideological positions of the past, however, but also of difficulties imposed by the organization of the archives themselves.

Insofar as Soviet government and party archives are organized primarily according to the institutional principle, the research of questions which did not fall under the purview of a particular institution or group of institutions can be difficult. Such is the case with Soviet nationality policy. Most specific nationality-policy institutions were abolished between 1934 and 1938. This fact complicates the very identification of relevant sources and requires research in a wide variety of archival

\footnotetext{
* The research upon which this paper was based was funded by the Berkeley Program in Soviet and Post-Soviet Studies, the Department of History, and the MacArthur-Mellon Program on the Politics of Cultural Identity, Institute of International Studies, University of California, Berkeley. I thank David Brandenberger, Daniel Orlovsky, Jan Plamper, Monica Rico, and Yuri Slezkine for their comments on initial drafts of this article.

1. "Nationality policy" is understood here as central policies relating to ethnicity, including questions of developing and controlling national cultures and languages, education, interethnic relations, and the appointment of party and state cadres. I do not include issues of "public opinion" or popular mood. Sources for such research (e.g., the svodki o nastroeniiakh) are not, to my knowledge, available for the late 1930 s onward at all systematically in central archives.
} 
collections. In this article, I discuss the problems of researching nationality policy in the archives from the mid-1930s to the early 1950s. My observations are based on approximately sixteen months of Ph.D. dissertation research in Moscow. ${ }^{2}$ I discuss three issues: 1) research difficulties resulting from the Soviet institutional structure; 2) the vagaries of specific collections; and 3) the kinds of documents which may be found in these collections. My concern is with the search for evidence in central archives about both central policies and local conditions. In the conclusion, I turn to the kinds of work we can produce by researching in these collections.

The Soviet institutional structure was determined by federalism and by the distinction among party, state, and security institutions. Despite oft-repeated notions of "sham" federalism, the Union republics formally did retain control of certain policy areas (e.g., education and culture). Although major directives on such policies came from the center, documents about their implementation and effects are located in the archives of the relevant republican and regional institutions. Researching such policies at central archives is problematic. ${ }^{3}$ Likewise, the shifting divisions of authority among party and state institutions over time offer opportunities and drawbacks for historical research. The uneven availability of the materials of the security apparatus, especially at the center, creates gaps in attempts to reconstruct important aspects of the policy process.

The XII Party Congress (1923) established the basic institutional features of early Soviet nationality policy, which were maintained until the promulgation of the 1936 Constitution. These features were: 1) Responsibility for the oversight of policy implementation was given to state institutions. Special departments for nationalities policy, such as the Nationalities Department of the All-Russian Central Executive Committee (Otdel natsional'nostei VTsIK), were created under the auspices of Union-republican Central Executive Committees (TsIK). ${ }^{4}$ In principle these structures were guided by the Council of Nationalities of the AllUnion Central Executive Committee (Sovet natsional'nostei TsIK SSSR), where several officials (instruktora) for nationality policy worked. 2) The actual

2. The dissertation is Stalin's nations: Soviet nationality policy between planning and primordialism, 1936-1953 (Department of History, University of California, Berkeley, forthcoming 1999). I conducted research in the collections of six Moscow archives: the Gosudarstvennyi Arkhiv Rossiiskoi Federatsii (GARF), Rossiiskii Gosudarstvennyi Arkhiv Ekonomiki (RGAE), Rossiiskii Gosudarstvennyi Arkhiv Literatury i Iskusstva (RGALI); Rossiiskii Tsentr Khraneniia i Izucheniia Dokumentov Noveishei Istorii (RTsKhIDNI), Tsentr Khraneniia Dokumentov Molodezhnykh Organizatsii (TsKhDMO), and Tsentr Khraneniia Sovremennoi Dokumentatsii (TsKhSD).

3. One may of course object that research on nationality policy should be conducted primarily at local archives. If one is searching for a coherent, centrally-directed nationality policy, however, relying on local studies can skew our understanding of broader questions. No nationality is "typical," and, indeed, nationality policy as I conceive it here is concerned with what the regime's "approach" to nationality itself was. Naturally, local studies can contribute to this, but they cannot substitute for sustained research, focused on numerous nationalities. This is accomplished best at central archives.

4. These structures were established after the abolition of the RSFSR People's Commissariat of Nationalities' Affairs (Narkomnats) in 1924. 
implementation of policies was left to the relevant Commissariats, some of which created special institutions for the purpose.5 3) Central party institutions specifically identified with particular nationalities (the various "nationality sections") were abolished with the reorganization of the Central Committee (TsK) apparatus in 1930, and appear to have had minimal influence before that. ${ }^{6}$ In short, state institutions managed nationality policy on the day-to-day level. The Politbiuro and Orgbiuro TsK naturally continued to take substantive political decisions on nationality policy.

This institutional picture gradually changed. The centralization of economic policies and multiplication of economic ministries after 1928 reduced the autonomy of republican and local soviet institutions. Likewise, the increased interference of the Central Committee in educational and cultural affairs in the 1930s led to centralization of standards and curricula and an erosion of republican autonomy in those areas. Most important was the institutional reorganization associated with the 1936 Constitution. The manifold responsibilities of the AllUnion TsIK and VTsIK, including those in nationality policy, were curtailed. The supreme soviets established by the new Constitution fulfilled far fewer functions pro-forma debates on the budget, reception of citizens' appeals, and the like. No nationalities departments were created within their structures. Most central ministries also lacked such dedicated institutions.

Thus, for the period of the 1920s and 1930s research into nationality policy can follow the activities of the TsIK, VTsIK, and Narkomnats RSFSR, as well as central party structures. These sources are often uneven, and one cannot expect to find materials on all republics or regions in equal proportions. Nevertheless, the finding aids (opisi) are detailed and the collections reasonably well organized.7 They also provide a jumping-off point for research in other state and party collections. After 1938 , to repeat, no specific party or state, central or regional, institutions were responsible for developing or implementing nationality policy. It would be mistaken to assume that, as a result, there was no Soviet nationality policy after this time. The research problem is where to look in the archives for relevant documents, a task that requires a certain amount of creativity on the part of the researcher.

5. The most important of these was the Committee for the Education of National Minorities of the RSFSR (Komnats Narkomprosa RSFSR), which existed, through various name changes, from 1918 to 1934. Its collection is held at GARF, f. a-296.

6. There were also TsK structures created to manage specific regions, such as the Central Asian Bureau (Sredazbiuro TsK) (1922-1934) and the various "plenipotentiaries" (upol'nomochennye TsK) for Latvia, Lithuania, Estonia, Moldavia, and Uzbekistan in the postwar period. But the significance of these lies in the weakness of local state and party institutions in certain regions, rather in the need for a nationality-policy "department." They were also temporary. There is a dedicated collection for each at RTsKhIDNI.

7. A description of these collections would go beyond my focus here. The best study to make use of them is Terry D. Martin, An Affirmative Action Empire: Ethnicity and the Soviet State, 1923-1938 (Ph.D. Dissertation, Department of History, University of Chicago, 1996). It should also be noted that the card catalogue at GARF (and the electronic catalogue upon which it is based) includes documents on nationality policy only until 1937-1938 precisely because of the lack of dedicated nationality-policy institutions after that time. 
One must work in two sorts of collections. First are the highest institutions of the party and state: the USSR and RSFSR Councils of People's Commissars (Sovnarkom), the Orgbiuro, Secretariat, Politbiuro, and departments of the apparatus of the TsK, and the Party Control Commission (KPK). Second are central branch institutions, such as the Ministry of Higher Education (MVO SSSR) and its predecessor the All-Union Committee for Higher Education (Vsesoiuznyi komitet po vysshei shkoly, VKVSh), and the RSFSR Commissariat (after 1946, Ministry) of Education (Narkompros). ${ }^{8}$ My focus on branch institutions covering culture and education naturally reflects my own interests, but research within the collections of other branch institutions encounters similar issues.

Researching nationality policy in these collections can be frustrating, but rarely fruitless. The collection of the RSFSR Narkompros can compensate for the lack of an All-Union Education Ministry. Most Union republics followed its lead, and Narkompros administered the schools of many nationalities. Unfortunately, for many years there is no systematic documentation for its Department of NonRussian Schools (Otdel nerusskikh shkol)..$^{9}$ One must rely on reports (otchety) of the regional educational authorities, and the occasional discussion of education in a particular autonomous republic or region at the ministry's collegium. ${ }^{10}$ Given the lack of horizontal bureaucratic relations in the Stalinist system, correspondence between Narkompros RSFSR and the educational institutions of other Union republics seems to have been minimal. I did not find any such correspondence in

8. Two other collections of interest to researchers on nationality policy are the Committee on Religious Affairs of the Council of Ministers (Sovet religioznykh kul'tov pri SM SSSR), held at GARF, f. r-6991; and the NKVD's Deportations Department (Otdel po spetspereselentsam GULAGa), held at GARF, f. r-9479. I do not discuss these collections here. The materials of the latter have been used extensively. See especially Deportatsiia narodov SSSR (1930-1950-e gody). Dokumental'nye istochniki TsGAOR SSSR (Moscow, 1992); N. F. Bugai, ed., Iosif Stalin - Lavrentiiu Berii: "Ikh nado deportirovat"” (Moscow, 1992); and N. F. Bugai, L. Beriia - I. Stalinu: "Soglasno Vashemu ukazaniiu” (Moscow: AIRO-XX, 1995). As for the materials of the Commission on Religious Affairs, these cover policies towards officiallyrecognized religious organizations; of particular interest are reports from its regional officials about both sanctioned and unsanctioned religious activities (op. 3). A small portion of the materials of its central apparatus is catalogued in Arkhivno-informatsionnyi biulleten', 11-12 (1996).

9. See the opis' for Narkompros RSFSR for 1947-1952: GARF, f. a-2306, op. 71, d. 1, 1. ii. After the abolition of the Komnats in 1933, responsibilities for non-Russian schools were distributed among the various directorates of Narkompros RSFSR. In 1938 a single department was re-established ("Ob organizatsii edinogo otdela nerusskikh shkol," Sbornik prikazov i rasporiazhenii po Narkomprosu RSFSR, 15 (1938): 3). As for the missing materials, when the Narkompros collection was transferred to the former TsGA RSFSR in the 1960s, much of its collection was apparently lost or misfiled (personal communication from David Brandenberger, April 30, 1998).

10. There are many such reports in the materials of the Main Schools Directorate (Glavnoe upravlenie shkol) for the years 1947-1952 (GARF, f. a-2306, op. 71, d. 1). Similarly, there are many otchety of pedagogical vuzy in the materials of the Main Directorate of Higher Education (Glavnoe upravlenie vuzov) (GARF, f. a-2306, op. 71, d. 4) for these same years. For earlier years (1924-1947) see op. 70, d. 1, chast' 2-3 (materials of the various sub-ministerial structures with responsibility for schools). Stenograms of the collegium can be found in op. 70 , d. 1 (the ministerial secretariat for 1947-1952), and in op. 69 (the same, for 1925-1947). 
my own research, nor evidence of regularized inter-republican ministerial meetings such as occurred in the $1920 \mathrm{~s} .{ }^{11}$

The collection of the Central Statistical Administration (Tsentral'noe statisticheskoe upravlenie - TsSU) adds significantly to the statistical collections on education and culture published by the regime. The educational authorities of the Union republics submitted a common form to TsSU each year indicating numbers of schools and students by grade level and language of instruction. It is thus possible to follow the trends in the provision of native-language education for non-Russian students by Union republic. However, these forms do not indicate the ethnicity of students as a category separate from that of the language in which they studied. As a result, it is difficult to determine the numbers of non-Russians studying in Russian-language schools. Such data is scattered throughout the Narkompros collection, particularly in the regional reports mentioned above. ${ }^{12}$

Because policy in higher education was centralized in a dedicated institution after 1936, finding material on nationality policy in that sphere should be easier. The collection of the All-Union Higher Education Committee (VKVSh, 19361946 ) is quite rich and well-organized. One can find much there on the problems of non-Russian universities and students. ${ }^{13}$ Research is more difficult in the collections of the Ministry of Higher Education, which replaced VKVSh in 1946. Systematic documents of some parts of the central apparatus of the Ministry appear to be missing, although yearly reports of individual institutions of higher education (vuzy) are available in abundance. The stenographic records and protocols of meetings of the ministerial collegium are listed in the opis' only by the date of meeting, with no indication of issues addressed. ${ }^{14}$ Those working on the history of Soviet higher education might find this a nuisance, but would probably want to read through all of the meetings for a particular series of years. Those working on a

11. Such materials have been published for the early 1920s: Protokoly soveshchanii narkomov prosveshcheniia soiuznykh i avtonomnykh respublik, 1919-1924 gg. (Moscow: Nauka, 1985). See also Kul'turnoe stroitel'stvo v SSSR, 1917-1927. Razrabotka edinoi gosudarstvennoi politiki v oblasti kul'tury (Moscow: Nauka, 1989).

12. These are at RGAE, f. 1562, op. 17. The schools statistics for the mid- and late 1930s are rather disorganized; from the mid-1940s onward the collection is more systematic. The TsSU collection also offers many other statistics on culture, education, and society. Since these were sent by regional institutions and collated at the center, their validity does depend on the accuracy of regional statistics.

13. The VKVSh collection is located in GARF, f. r-8080. Opis' 1 contains materials of the secretariat and the structures of the Committee. More of the latter are also contained in opis' 2 .

14. MVO documents are in GARF, f.r-9396. Opis' 1 contains materials of the central apparatus (kantselariia), including stenograms of the collegium and correspondence with the TsK. Opis'2, materials of the Universities Directorate (Glavnoe upravlenie universitetov, ekonomicheskikh i iuridicheskikh vuzov), consists almost entirely of otchety, as do the opisi covering technical vuzy (op. 3-6). Also of interest are op. 13 (Upravlenie kadrov) and op. 23 (Inspektsiia pri Ministre). Institutions of secondary specialized education (tekhnikumy) were also under the authority of the MVO; correspondence with Union-republican authorities on them is in op. 15 (Upravlenie srednikh spetsial'nykh uchebnykh zavedenii). 
particular aspect of higher education, however, will find this practice leading to a considerable investment of time with questionable return. ${ }^{15}$

Because of the very size, research in the collections of the highest political institutions presents different problems. Systematic work in the collections of the USSR and RSFSR Councils of Ministers and, especially, the Communist Party Central Committee requires a good deal of orientation. The collection of the apparatus of the USSR Council of Ministers is well- organized. Correspondence (perepiska) between it and Union-republican ministries provides an entry into both questions of center-periphery relations and of decisions taken at lower levels of the federal ladder. Regardless of where policy choices were made, the center ultimately had final approval. Union-republican educational authorities, for example, regularly appealed to the center for additional funds. The correspondence between the Council of Ministers and the Ministries of Education of the Union republics consists of a run of several files for each year. It is a valuable source, although regional-central correspondence in other policy areas is not always so organized. ${ }^{16}$

Undoubtedly the most useful materials are those of the Central Committee, although here as elsewhere the lack of a "nationalities department" or some similar structure requires digging through many opisi. ${ }^{17}$ Materials of the various TsK departments have the advantage of breadth of scope, and the disadvantage of being wholly unsystematic, a result of their very functions - a combination of oversight, investigation, and drafting of Secretariat decisions. One can find very much indeed about disputes in Kazakh historiography in 1951, korenizatsiia (indigenization) of factory workers in Uzbekistan in 1947, or Russian-language instruction in Estonia in 1949 , but very little about any of these issues over a run of years. ${ }^{18}$ The TsK departments were often organized on geographic principles, with sub-sections for specific republics. This structure was not retained when the materials were archived, although some files are defined geographically. In short, one cannot necessarily expect to read all of the materials on, for example, non-Russian schools located in the TsK collections in order to find a relatively complete picture of such schools. The materials of the Central Committee apparatus are best used to direct

15. I should also note the poor quality of the microfiche upon which these materials are preserved. Researchers should request the original files.

16. There is a regular, and secret, opis' for each year for the apparatus (Upravlenie delami) of the Council of Ministers. They are at GARF, f. r-5446. Secret opisi are apparently not available to researchers for the post-1941 years.

17. In particular, I worked with materials of the various propaganda and educational departments (RTsKhIDNI, f. 17, op. 125, 126, 132, 133), and the party organs departments (op. $88,122,131)$.

18. RTsKhIDNI does not have the materials of the TsK departments that were assigned the highest level of secrecy (osobaia papka). Apparently, these are held at TsKhSD, although they are not available for use. See L. Kosheleva, "Istoriia organizatsii fonda Tsentral'nogo komiteta KPSS i sostoianie nauchnogo spravochnogo apparata," paper presented at the conference “Assessing the new Soviet archival sources," Yale University, May 16-18, 1997. 
more detailed research in other collections. At the very least, they offer quite detailed information about specific events, controversies, or decisions. ${ }^{19}$

The materials of the Party Control Commission (KPK), held at the TsKhSD for the years after 1936, are also rich sources. In particular, opis' 6 contains the correspondence between the Commission and its regional representatives for the years 1939-1948. Much of these details the implementation, and lack of implementation, of TsK decisions. There are several dedicated files for each region and republic. In this collection, one can also find confidential reports about personal relations within the local party elite and reports on popular mood. ${ }^{20}$ Overall, materials of the KPK are similar in scope to those of the TsK departments.

For key political decisions, the decisions (protokoly) and materials of the Secretariat and Orgbiuro are crucial..$^{21}$ But their very breadth means that one must spend much time to use them at all systematically. There is a card catalogue that lists their decisions, but this retains the vague language in which these were often officially titled (e.g., innumerable decisions described as "Vopros TsK $K P(b)$ Kazakhstana" or "Vopros Iakutskogo obkoma $V K P(b)$ ", which give no indication as to contents). Major decrees (postanovleniia) are generally easier to identify. While Secretariat and Orgbiuro decisions and materials are invaluable sources, the researcher without years of time to spend at RTsKhIDNI should rely on the documents of the TsK departments for clues to the agenda of the Secretariat and Orgbiuro themselves. As for the Politbiuro, examination of its protocols after the late 1930s indicates a focus mostly on foreign affairs, decisions of great moment during the War, long-term economic plans, and the granting of awards and medals. Detailed materials about its decisions remain unavailable to most researchers at the Presidential Archive. ${ }^{22}$

Finally, a word must be said about materials on cadres policy. This includes general guidelines for appointing party and state officials, aggregate nationality statistics of cadres, and the tracing of particular appointments. For the latter, the collection of the Secretariat and Orgbiuro is indispensable. There one can find decisions on both individual appointments to many state and party positions, as

19. One important exception to the irregular nature of the TsK departmental materials are the special reports (svodki) prepared by the informational section of the Party Organs Department on activities and decisions of regional party organizations. These are held at RTsKhIDNI, f. 17, op. 88 for the years 1941-1952. They vary in both content and regularity over time.

20. TKhSD, f. 6, op. 6. The other opisi of this collection contain protocols of the KPK. The opisi and dela of this collection have been microfilmed and are part of Chadwyck-Healey's collection "Archives of the CPSU and Soviet State." I used them at the Hoover Institution Archive, Stanford University.

21. The decisions of the Secretariat and Orgbiuro (RTsKhIDNI, f. 17, op. 114 and 116) are stored in separate files from materials to decisions after 1934 (op. 114, 117-119). The materials include documents distributed for discussion among Secretariat and Orgbiuro members, and also information about the implementation of decisions.

22. However, the original decisions of the Politbiuro (RTsKhIDNI, f. 17, op. 163) do sometimes include supplementary materials, which tend to be richer for the earlier 1930s and 1920s. On a recent (July 1998) trip to Moscow, the Politbiuro originals were no longer available to researchers. 
well as wholesale appointments of regional party bureaus. Typically, a brief biography (kharakteristika) for each appointment is available in the collection of materials to the Secretariat and Orgbiuro protocols. Tracing a great many appointments in this collection, however, is an admittedly tedious process.

General policy guidelines and aggregate statistics on cadres are more difficult to find. From 1939 to 1948, cadres policy was centralized at the Central Committee's Cadres Directorate (Upravlenie kadrov). However, neither the opis' nor the materials of the collection are open for use. ${ }^{23}$ Its unavailability is a serious handicap for researching many aspects of Soviet political history at this time. ${ }^{24}$ In 1948, the responsibilities of the Directorate were distributed throughout the Central Committee apparatus. Most important was the Department for Party, Komsomol, and Trade-Union Organs (Otdel partiinykh, profsoiuznykh i komsomol'skikh organov), the opis' of which (f. 17, op. 131) is suspiciously light. The materials of the TsK Statistical Department (f. 17, op. 7) at RTsKhIDNI only reach 1941. For these reasons, securing reliable and systematic data on the ethnicity of party and state cadres is almost impossible. The Organizational-Instructor Department of the RSFSR Council of Ministers did collect some data on the ethnicity of state officials of the autonomous republics and regions. ${ }^{25}$ However, neither the USSR Council of Ministers nor the Supreme Soviet appears to have collected similar statistics on personnel on an all-Union level. ${ }^{26}$

Given the structural problems of researching nationality policy in central archives, what kinds of documents is one likely to encounter there? First, the very concept "nationality policy" (natsional'naia politika) is almost never the subject of memoranda or decrees after the late 1930s, although it appears frequently before then. ${ }^{27}$ Likewise, the term "korenizatsiia" occurs far more rarely than in documents of the 1920s and 1930s. In the 1940s and 1950s, the word most often appears to describe the use of the native, non-Russian, language in schools. Cadres policy documents tend to use terms such as "podgotovka natsional'nykh kadrov" (training of nationality cadres). What one does find are exchanges of materials between the center and regions on specific issues and decisions. These are sites of centerperiphery contact, where the resolution of particular questions, rather than general policy directives or fundamental principles, are at issue. I divide these sites of contact into two categories: routinized communications between center and periphery, and "irregular" batches of documents focusing on unique, often politically sensitive, events.

23. The official explanation for the closure of the collection of the Cadres Directorate is the presence of many "personal questions" in its files.

24. One can get an idea of its scope of authority by tracing its correspondence with other institutions, both in the TsK itself and in the collections of the ministries.

25. For these statistics, see GARF, f. a-259, op. 6 and 6a.

26. I appreciate the help of the head of the collection of the Council of Ministers at GARF, S. V. Somonova, who searched for such statistics without success.

27. In my own research I found only one example of a TsK decree from the late 1940s in which the general state of nationality policy was a subject of a decision. 
By routinized communications between center and periphery, I mean several genres of documents that by their nature appear many times in the archives. I describe below four such genres of documents: memoranda prepared by the TsK apparatus (dokladnye zapiski), regional reports to the center (otchety), "appeals" from the regions to the center, and stenographic records (stenogrammy) of meetings of ministerial collegia.

The first kind of document should be familiar to anyone who has worked with fond 17 at RTsKhIDNI - investigations of regional party organizations by the staff of the TsK, sometimes of a particular problem or event, other times based on a "schedule of work" for the department in question. Often these investigations led to a TsK decree or were themselves triggered by earlier TsK decisions. What can be said about these memoranda as a genre? First, the supporting documents upon which they are based often have not been preserved. In cases where they are the product of a visit to the region by a central official, this would include notes taken by the drafters of the document on their trip. Notes or records of meetings with regional officials at TsK offices, often mentioned in such documents, are rarely available. Sometimes materials sent from regional authorities do not accompany such reports, which usually contain impressionistic accounts of trips to the regions. Investigators cite statistics (e.g., of the nationality composition of administrative institutions, failure rates in schools, etc.) in an irregular and unsystematic way, relying on examples from just one year, one region of a republic, or even one school or party organization, to portray a "typical" picture. Commonly placing blame on local party and state institutions, they retain the natural bias of central institutions, and are written with the Soviet bureaucrat's stock vocabulary of concepts (e.g., about "shortcomings" (nedostatki), "unsatisfactory work" (neudovletvoritel'naia rabota), etc.). In short, the memoranda of the TsK apparatus are useful for understanding the milieu of the central party apparatus and its decisions. They must be used with care as sources for the "true picture" of activities on the ground in the regions.

The report on work of a regional party organization, in principle sent regularly to the center, is a second kind of regularized communication. ${ }^{28}$ Written in formalbureaucratic style, organized on the basis of the ideological catchwords of the day (e.g., with sections for "party-organizational work", "party-political work," etc.), they are full of facts and statistics (e.g., the number of party members engaged in "individual study" of Marxist-Leninist texts, rates of turnover for raikom secretaries, etc.). Surprisingly (or perhaps not so surprisingly), reports from nonRussian party organizations often neglect issues of ethnicity. Statistics of party organizations, to take an example, are often not broken down by nationality, although the categories of class origin, gender, and education are omnipresent. In short, these documents too tell us more about what kind of information the center demanded from the regions on a regular basis, and less about the actual conditions in regional party organizations. Priority in these reports is given to describing the 
implementation of specific TsK decrees about the regional organization in question.

Another kind of report was sent regularly by regional educational authorities to the RSFSR Ministry of Education and by individual vuzy to the Higher Education Ministry. ${ }^{29}$ These do often provide valuable information about local education conditions, the numbers of schools by language of instruction, as well as detailed descriptions of problems of instruction of specific subjects (including, naturally, Russian - and native - language instruction in non-Russian schools). They also frequently give voice to local complaints about policies of the center. Most important, these reports allow the activities of local educational institutions to be followed over time across numerous nationalities. ${ }^{30}$ Yearly reports from vuzy often offer a breakdown of students and faculty by ethnicity, clues about which languages were used in instruction, and the kinds of courses and research pursued by students and faculty alike.

A third kind of source is the "appeal" from a regional party or state official to the center, usually for specific resources. They are sprinkled throughout the collections of the TsK and Council of Ministers. Typically, the decisions of regional institutions included points requesting budgetary allocations from the center, approval for certain decisions, and the sending of personnel from the center to the region in question. Such requests were sent to the apparatus of the TsK and Council of Ministers, which would then prepare memoranda on whether to approve the given request. Reading through these documents gives one an idea of the extent of hyper-centralization of the Stalinist state. Rather minor questions (e.g., opening a new school, or adding one staff member to a raikom) usually required the ultimate approval of the center. In their appeals, regional officials present information about local conditions to support their demands, and often offer explanations for local problems that conflict with the conclusions of the central apparatus. They are thus useful entries into center-periphery conflict. Typically, appeals consist of a two- or three-page letter and occasionally include the kinds of supporting documents which would enable the researcher to determine the "real" social, economic and cultural conditions surrounding their requests. Likewise, the memoranda drafted for high central officials by their apparatus in response to these appeals are relatively short, usually restating briefly the arguments of regional officials with advice on approval of the request.

Finally, a most useful genre is the stenographic record of meetings of ministerial collegia. ${ }^{31}$ The way in which agendas were set for such meetings remains mysterious. While certain issues, such as preparations for the coming school year, or plans for vuz admissions, made agendas several times each year, examinations of

29. See notes 10,13 , and 14 for the locations of these.

30. Whether regional reports exist in the collections of other central ministries is a question I cannot address.

31. See notes 10,13 , and 14 for locations of these in the collections of the various educational authorities. 
education problems in specific regions or of specific vuzy appear quite randomly. At the same time, enough of these exist to consider them a regular site of centerperiphery contact, and one of special value. First, they record direct conversations among officials which reflect political, or at least bureaucratic, conflict, often in stark terms. Second, they are usually accompanied by rich supporting materials prepared by regional and central bureaucrats in the kinds of detail rare for centrally produced documents alone. Of course, given the nature of the Stalinist state and its officialdom, one should not expect free debate in such meetings. Differences of opinion, however, appear quite frequently.

The nature of these four kinds of regularized communications between center and periphery lead to a conclusion that should be no surprise to anyone who has worked extensively with documents in the late-Stalin (and, perhaps, post-Stalin) period. Most such documents were written in routinized, bureaucratic-ideological language and provide limited entry into the "thoughts" of their authors. Their information is compartmentalized. Documents sent to the Central Committee were routinely labeled completely secret (sovershenno sekretno), but this level of secrecy was clearly below that considered necessary for the transmission of truly sensitive information.

If the systematic examination of routinized communications between center and periphery often provide uneven or unsatisfactory information, then irregular communications can flood the researcher with detail. These defy exact description, and indeed are really batches of inter-connected documents distributed through several archival files. Usually they relate to a scandal or political crisis in a region, often triggered by the TsK's receipt of denunciations or letters of complaint from interested parties, by newspaper editorials, or by investigations by the TsK apparatus itself. Often the exact origins of the interest of the center cannot be traced.

Batches of such documents are quite common in the collection of the TsK precisely because it was its practice to take an interest in local affairs on the basis of such scandals or political blow-ups. One example from my own research is the case around the dismissal of N. Mazin, the First Party Secretary of the Kabardinian party organization from 1944 to 1948. Mazin was removed in 1948, in large part for failing to ensure the appointment of ethnic Kabardins to party and state positions in the republic. Documents about his case are distributed in several opisi in fond 17 at RTsKhIDNI. Tracing the origins and consequences of such cases requires creative digging (in this case, ordering everything I could find related to the Kabardinian ASSR in 1948) if one is to obtain a complete picture. ${ }^{32}$ These sorts of cases are naturally of special interest to those researching the issue in question, but they also provide very rich documentation about local political relationships and social and cultural conditions. Yet for all the local color they provide, such cases remain "snapshots" of a very specific place and time, and rarely provide sufficient 
information beyond the scandal in question to allow for systematic research, either about the region in question, or about the way in which the center reacted to the kind of problems presented.

The consequences of the Soviet institutional structure for archival research, and the kinds and depth of documents that may be found in central archives, create two dilemmas for researchers interested in nationality policy. The first can be termed the problem of "local nationalism versus great-power chauvinism," to borrow the official Soviet catchwords. The impact of the federal system makes the choice between local or regional studies and research on the Soviet Union as a whole starker than it otherwise might be. Beyond traditional debates about micro- and macro-history is the fact that work on the Soviet Union as a whole itself is difficult, perhaps even impossible, on certain questions because necessary sources are not available at central archives. Research in dozens of regional and local archives is rarely feasible for the individual scholar. Yet, the diversity of the country means that many local studies are of interest only in their particularity, rather than in the general lessons that may be drawn from them. This is especially true of nationality policy, where there has been a tendency in the historiography for studies to focus on a particular ethnic group. The tone of such studies has often been a sympathizing nationalism, with one of two results: 1) the extent to which local problems and policies were results of a common nationality policy is not taken into account, and thus the ethnic group in question is seen as a particular victim of the Soviet regime; or 2) the experience of the nationality under study is transformed into that of all non-Russian nationalities. Of course, relying entirely on the centrally produced sources which dominate central archives can lead to the opposing danger of russocentrism.

The second observation lies in the nature of the sources produced by the state and party bureaucracy themselves at this time in Soviet history. Routinized sources are often dull, and offer minimally useful information for the historian. Yet apart from the fact that in some cases these are the great majority of sources available, they are also the kinds of sources that permit us to speak of typicality, of change over time, of fundamental trends. Systematic research on such trends require systematic sources. In this respect, the historian is the prisoner of the kinds of data collected by the regime, and its choices can create serious gaps in our research. The more sensational sources, those irregular sites of the ironic, tragic, and bizarre, of which there are indeed plenty, are dangerous precisely because of their irregularity. It is more tempting to use them, not only because they are interesting, but because they are common in the very central archives from which, hopefully, we can derive a general picture of Soviet history. But if we rely too much on such sources, we risk turning Soviet history into a series of random scandals and explosions.

Obviously, the trick must be to balance bureaucratic banalities with the sensational, eschewing over-reliance on either. To expand our understanding of Soviet nationality policy, and to integrate it into the historiography, it is critical that it be treated as a whole and that the ideological and political positions of the past be 
overcome. The opening of Soviet archives is a necessary, but not sufficient condition for this goal.

University of California

Department of History

3229 Dwinelle Hall

Berkeley, CA 94720

e-mail:peterab@socrates.berkeley.edu 